\title{
A new species of Alpaida (Araneae, Araneidae) from Southeastern Brazil
}

\author{
Pedro de S. Castanheira \& Renner L. C. Baptista
}

Laboratório de Diversidade de Aracnídeos, Universidade Federal do Rio de Janeiro, Av. Carlos Chagas Filho, 373, 21941-902, Ilha do Fundão, Rio de Janeiro, Brazil. (pedrocastanheira.bio@gmail.com; baptistr@gmail.com)

\begin{abstract}
Alpaida venger sp. nov. is described based on males and females from Pedra Branca State Park, Rio de Janeiro, Brazil. This species seems to be related to Alpaida scriba (Mello-Leitão, 1940) and Alpaida alticeps (Keyserling, 1879) due to similar body shape and color, but is easily distinguished by the very elongated median apophysis, the massive lobe of tegulum and the hooked paracymbium of male palp. Females have elongated epigyne as $A$. scriba, but can be distinguished by the wider lips and shorter scape.
\end{abstract}

KEYWORDS. Neotropical Region, spiders, taxonomy, Atlantic Forest.

RESUMO. Uma nova espécie de Alpaida do Sudeste do Brasil. Alpaida venger sp. nov. é descrita baseada em machos e fêmeas do Parque Estadual da Pedra Branca, Rio de Janeiro, Brasil. Esta espécie parece relacionada a Alpaida scriba (Mello-Leitão, 1940) e Alpaida alticeps (Keyserling, 1879) devido a similaridades no formato e cor do corpo, mas é facilmente distinguida pela apófise média muito alongada, ao particular lobo do tégulo e ao paracímbio em forma de gancho do palpo do macho. Fêmeas apresentam epígino alongado como $A$. scriba, mas podem ser diferenciadas pelos lábios mais largos e escapo mais curto.

PALAVRAS-CHAVE. Região Neotropical, aranhas, taxonomia, Floresta Atlântica.

The spider genus Alpaida O. P.-Cambridge, 1889 includes 86 Brazilian species from a total of 147 species and three subspecies in Neotropical Region (WORLD SPIDER CATAlOG, 2015). According to Levi (1988), they are diurnal Neotropical orb-weavers, easily recognizable by the bright and glabrous body with orange carapace. Also, males have a narrow cephalic portion of carapace; palp with embolus, radix and terminal apophysis fused and a mushroom-shaped paramedian apophysis, a character shared with Edricus $\mathrm{O}$. P.-Cambridge, 1890. Females may be recognized, on the other hand, by a wide cephalic portion with black-ringed eyes and by the typical epigyne. This structure is transverse and sclerotized, with posterior lips and a middle portion coming out into a triangular lobe or scape. In posterior view, there is a median plate framed by a lip and with one copulatory opening at each side.

The first revision of the genus was carried out by LEVI (1988), with the redescription of 40 species that were previously misplaced in several other genera within Araneidae, alongside the description of 94 new species. After Levi's work, a handful of papers about the genus were published, adding 11 species and one subspecies to the genus (LeVI, 1992; Buckup \& MeYER, 1993; ABrahim \& Bonaldo, 2008; Framenau et al., 2009; Santos \& SANTOS, 2010; Buckup \& Rodrigues, 2011; Rodrigues \& Mendonça JR, 2011; Braga-Pereira \& Santos, 2013; Dierkens, 2014; DeZa \& Andía, 2014; Poeta \& Lise, 2015 and SATURNINO et al., 2015).

Pedra Branca State Park is a 12,500 hectares urban forest. It is the largest green area in the city of Rio de Janeiro and constitutes one of the last preserved areas of the Atlantic Forest biome in the city (OliverRa et al., 1995). The park is located in Jacarepaguá, western region of the city, $22^{\circ} 58^{\prime} 12.0^{\prime \prime} \mathrm{S}, 43^{\circ} 26^{\prime} 16.4^{\prime \prime} \mathrm{W}$. The spider fauna of the area has recently been explored in a standardized taxonomic survey, during the master studies of the first author, revealing a total of 371 species or morphospecies, where Araneidae was the second richest family with 47 species, seven of which belonging to the genus Alpaida. Data obtained from a spider inventory in Pedra Branca State Park revealed a new species: Alpaida venger sp. nov., described and illustrated here based on both sexes.

\section{MATERIAL AND METHODS}

Descriptions and terminology follow LeVI (1988) focusing on the relevant features of the species, without repeating common characters for the genera. The material examined was collected in 2013 and 2014 and is deposited at the Museu Nacional, Rio de Janeiro, arachnology collection (MNRJ; A. Kury) and Instituto de Biologia, Universidade do Brasil/Universidade Federal do Rio de Janeiro (UFRJ; R. Baptista). All automontage photographs of the preserved specimens were taken with a camera mounted on a stereoscope microscope and edited with Adobe Photoshop CS5 and Coreldraw X7. Samples for scanning electron were air dried and coated with goldpalladium and observed under a high vacuum microscope, from Instituto de Biologia, UFRJ. All the measurements are in millimeters and color patterns are described from specimens preserved in $75 \%$ ethanol.

\section{Alpaida venger sp. nov.}

(Figs 1-9)

Type-material. Holotype $\widehat{\jmath}$, BRAZIL, Rio de Janeiro: Rio de Janeiro, Pedra Branca State Park, Camorim, near Açude $22^{\circ} 58^{\prime} 08.3^{\prime \prime} \mathrm{S}, 43^{\circ} 26^{\prime} 38.5^{\prime \prime} \mathrm{W}, 342$ 

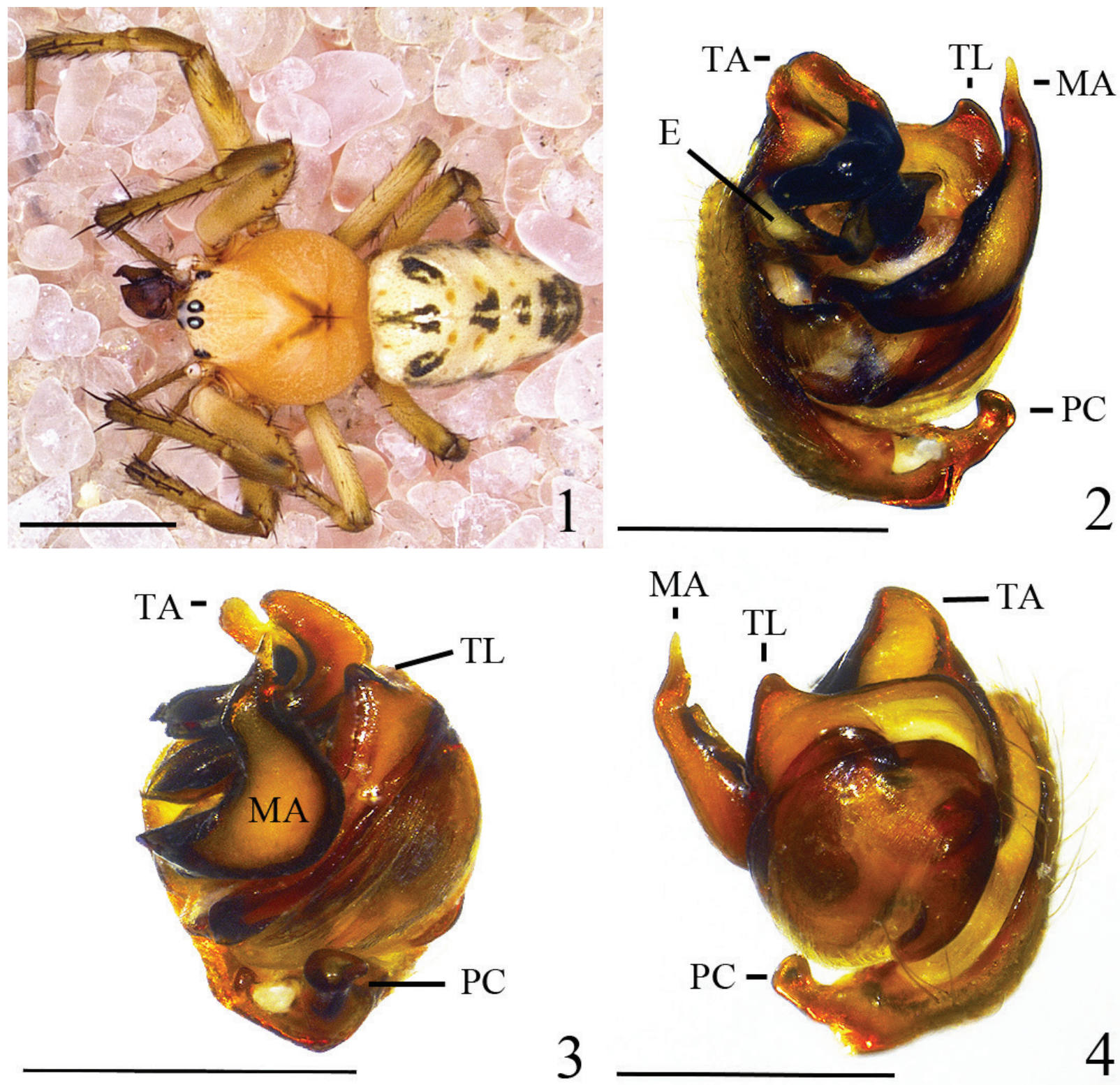

Figs 1-4. Alpaida venger sp. nov., holotype ${ }^{\Uparrow}: 1$, dorsal habitus; 2-4, left male palp: 2, ventral view; 3, retrolateral view; 4, dorsal view (E, embolus; MA, median apophysis; PC, paracymbium; TA, terminal apophysis; TL, tegular lobe). Scale bars: Fig. 1, 2 mm; Figs 2-4, 0.5 mm.

m, 01.VI.2013, R. Baptista coll. (MNRJ 06827). Paratypes: BRAZIL, Rio de Janeiro: Rio de Janeiro, Pedra Branca State Park, Camorim, Sede 22॰56’12.8’'S, 43॰26’29.1’W, 160m, ô, 15.IX.2013, P. Castanheira coll. (MNRJ 06830); q, 7.IV.2014, P. Castanheira coll. (MNRJ 06829); + same data of holotype (MNRJ 06828); ㅇ, 31.III.2014, P. Castanheira coll. (UFRJ 1002); 今ึ, 8.I.2014, R. Baptista coll. (UFRJ 1004).

Etymology. The specific name refers to the antagonist character "Venger", from the animated television series named and inspired on the game "Dungeons \& Dragons". The character has a single horn on the side of the head, resembling the long paramedian apophysis of the male palp.

Diagnosis. This species seems to be related to Alpaida scriba (Mello-Leitão, 1940) and Alpaida alticeps
(Keyserling, 1879) judging by the abdomen shape and color, the strong, crescent-shaped median apophysis and the massive and strongly sclerotized terminal apophysis (see Levi, 1988, fig. 187 and BuCKuP \& MeYER, 1993, fig. 3). The male of $A$. venger is distinguished from both species by its very elongated median apophysis, projected well beyond the apical margin of the cymbium, the lobe at the edge of tegulum placed distally and elongated hooked paracymbium (Figs 2, 5). In contrast to the short epigyne of $A$. alticeps, the elongated epigyne of $A$. venger is more similar to $A$. scriba, but differs by the stronger and wider lips and shorter scape (Figs 8, 9).

Description. Male (Holotype): Carapace, endites and chelicerae orange. Carapace with a brown V-shaped mark around fovea (Fig. 1). Legs yellow with brown patches on femur, patella, metatarsus and tarsus (Fig. 1). Eyes ringed in 


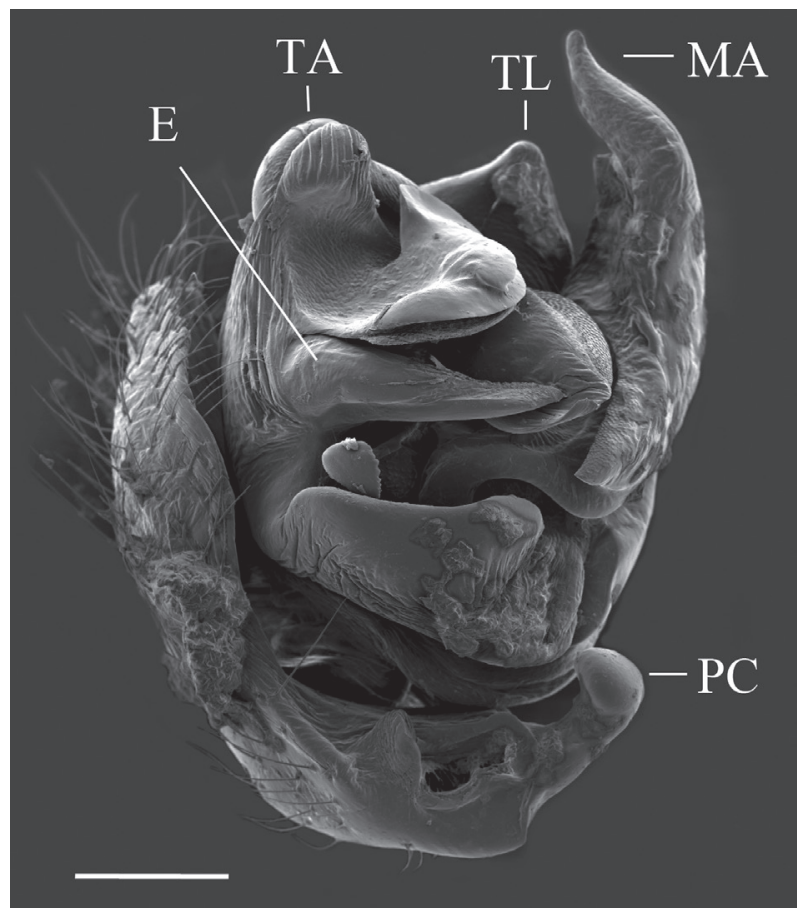

Fig. 5. Alpaida venger sp. nov., standard electron microscope photo of left male palp, ventral view (E, embolus; MA, median apophysis; PC, paracymbium; TA, terminal apophysis; TL, tegular lobe). Scale bar: 0.2 $\mathrm{mm}$. black (Fig. 1). Abdomen longer than wide, cylindrical, with a large rounded, terminal bulge, with three slightly marked lateral lobes (Fig. 1). Dorsum of abdomen yellow with some scattered small white patches, its first third with three pairs of black patches, median third with two pairs of black patches and posterior third with a big black area formed by six almost fused black patches (Fig. 1). Lateral part of abdomen with a median interrupted black stripe. Sternum pale yellow. Venter yellow with three slender, transversal black stripes, almost fused, on the distal third, forming a large black area covering the entire tip of the abdomen. Palp with long, crescent-shaped, median apophysis projected beyond the cymbium, with a lobe at its median region and the tip bent inwards in retrolateral and dorsal views (Figs 3, 4); embolus elongated and blade-shaped (Figs $2,5)$, terminal apophysis subquadrate, massive, very sclerotized, with distal lobe subdivided, bearing a rounded inner projection, and elongated, hooked paracymbium (Figs 2-5). Total length: 5.12. Carapace: 2.38 long, 2.21 wide, 0.98 high. First leg: femur 2.54, patella 0.82 , tibia 1.98 , metatarsus 2.00 and tarsus 0.89 . Second patella and tibia 2.52; third 1.61; fourth 2.69.

Female (Paratype MNRJ 06828): Carapace, endites, chelicerae, legs, eyes and sternum as in male (Figs 6, 7). Brown area around fovea absent (Fig. 6). Abdomen

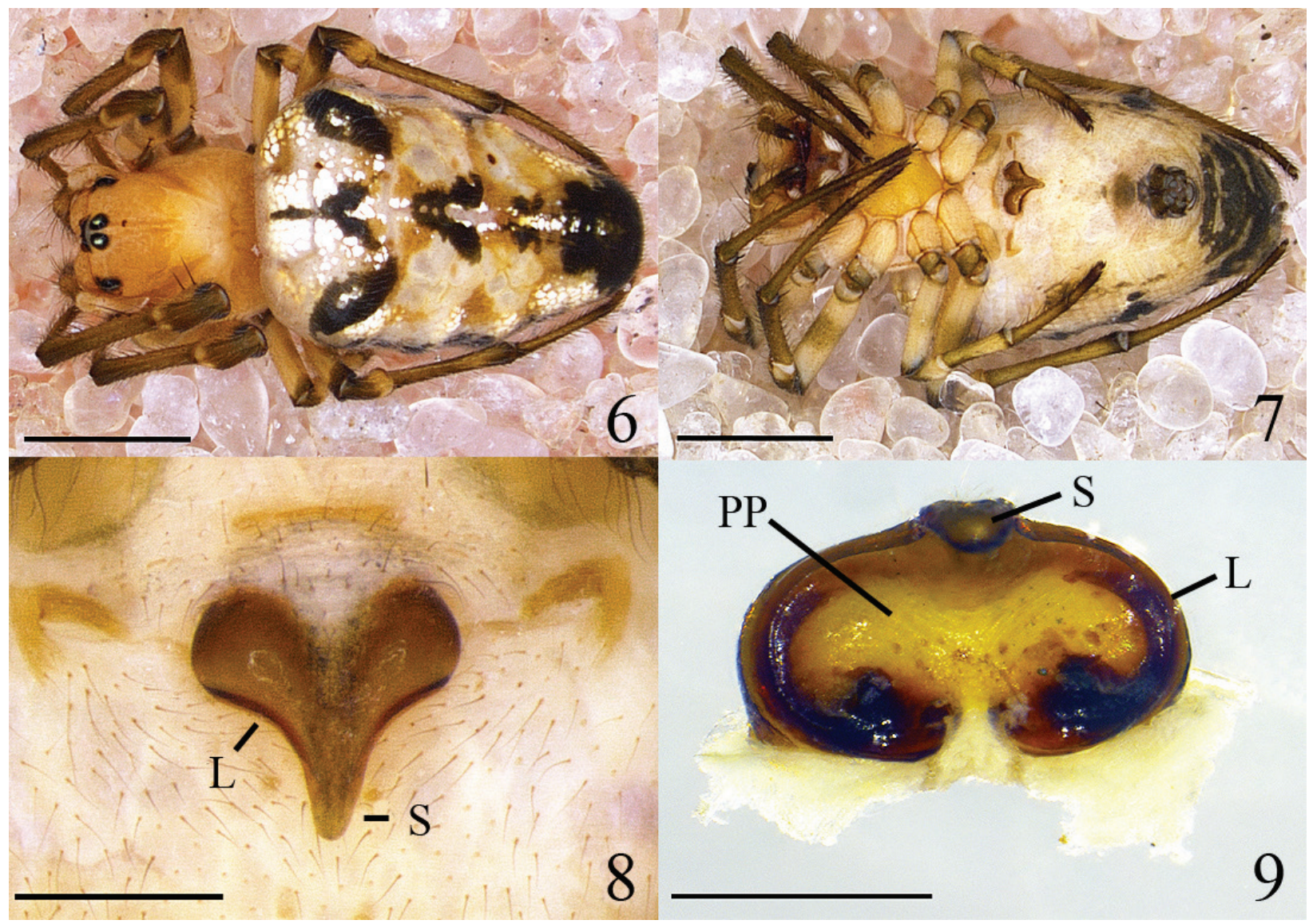

Figs 6-9. Alpaida venger sp. nov., paratype 9 . Figs 6-7, habitus: 6, dorsal view; 7, ventral view; 8-9, epigyne views: 8, ventral view; 9 , posterior view (L, lips; S, scape; PP, posterior plate). Scale bars: Figs 6, 7, 2 mm; Figs 8, 9, 0.5 mm. 
shape similar to male, but wider and with lateral lobes clearly visible (Fig. 6). Dorsum with color pattern similar to male, but with more extensive white patches, covering the proximal third, projecting posteriorly towards the distal median black patches, and also covering both laterals of the abdomen (Fig. 6). Epigyne heart-shaped, with large and wide rounded lips, with an elongated median scape, gradually tapering to its rounded, blunt tip (Fig. 8). Posterior plate, much wider than high and depressed in both sides (Fig. 9). Total length: 6.49. Carapace: 2.14 long, 1.99 wide, 0.94 high. First leg: femur 2.33, patella 0.97, tibia 2.10, metatarsus 1.32 and tarsus 0.77 . Second patella and tibia 2.47; third 1.17; fourth 2.39.

Variation. Males $(n=5)$ : total length, $4.18-4.74$; females $(n=10)$ : total length, $5.38-8.32$. The number of white patches and the shape and extension of the black patches vary among specimens. Living specimens usually have red patches around the median line and the posterior end of the dorsum of abdomen.

Other material examined: BRAZIL, Espírito Santo: Santa Teresa, Reserva Santa Lúcia (ca. 19 $58^{\circ} 10^{\prime \prime S}$, 40³1'55”W), O’, o , 07.IX.1988, R. Baptista, A. Kury \& A. P. Chaves coll. (MNRJ 06832). Rio de Janeiro: Rio de Janeiro, Pão de Açúcar (22॰56'55”'S, 43॰09'20”'W), $9{ }^{\lambda}, 3$,, XI.2004, E. H. Wienskoski coll. (MNRJ 5014), ô, 3j, II.2006, E. H. Wienskoski coll. (MNRJ 06831); Rio de Janeiro, Pedra Branca State Park (Camorim Sede 2256'12.8”'S, 4326'29.1”'W, 160 m), , 15.IX.2013, R. Baptista coll. (UFRJ 0992); (Camorim Açude 22 58'08.3”S, $43^{\circ} 26^{\prime} 38.5^{\prime}$ 'W, 342 m), 20, 5 ㅇ, 15.IX.2013, R. Baptista coll. (UFRJ 1000); , 31.III.2014, R. Baptista coll. (UFRJ

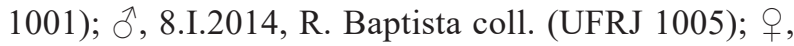
9.I.2014, R. Baptista coll. (UFRJ 1006).

Natural History. Alpaida venger sp. nov. is a fairly common species at Pedra Branca State Park. The four collecting trips in one year span yielded 6 males and 11 females. They were found mostly in second growth patches of Atlantic Forest, varying from $\mathrm{ca}$. 130-350 meters high. All mature specimens were caught on the Camorim core of the park, located at the Atlantic side of the Pedra Branca range. Most specimens were collected from orb webs at night. Their webs were usually situated at $50-150 \mathrm{~cm}$ above ground level, among the branches of vegetation. Some species were collected by sweeping or beating vegetation during the day.

Distribution. Known from Pedra Branca range and Pão de Açúcar Mountain, both in the city of Rio de Janeiro, state of Rio de Janeiro, and also known from Santa Teresa, state of Espírito Santo, both in Southeastern Brazil.
Acknowledgments. We thank all the staff from Pedra Branca State Park for the help during the survey which made possible the collection of this new species and the INEA for allowing our work in the park. We are also thankful to Carla Barros and Adriano B. Kury for depositing the species at MNRJ, Marcelo Sales for the help on taking the SEM photo, Ricardo Monteiro and Margarete Macedo for the use of their automontage microscope and Denis Rafael Pedroso and Diogo Tinoco Castro for the help on editing the photos and for making comments on the text. This work was financed by a Master CAPES (Coordenação de Aperfeiçoamento de Pessoal de Nível Superior) grant.

\section{REFERENCES}

Abrahim, N. \& Bonaldo, A. B. 2008. A new species of Alpaida (Araneae, Araneidae) from Caxiuanã National Forest, Oriental Amazonia, Brazil. Iheringia, Série Zoologia 98:397-399.

Braga-Pereira, G. F. \& Santos, A. J. 2013. Two new species of the spider genus Alpaida (Araneae: Araneidae) from restinga areas in Brazil. Zoologia 30:324-328.

Buckup, E. H. \& MeYer, A. C. 1993. Sobre o macho de Alpaida scriba (Araneae, Araneidae). Revista Brasileira de Entomologia 37(2):353354.

Buckup, E. H. \& Rodrigues, E. N. L. 2011. Espécies novas de Alpaida (Araneae, Araneidae), descrições complementares e nota taxonômica. Iheringia, Série Zoologia 101:262-267.

DeZA, M. \& Andía, J. M. 2014. Two new species of the orb-weaving spider genus Alpaida (Araneae, Araneidae) from Peru. Zootaxa 3827(1):67-77.

Dierkens, M. 2014. Contribution à l'étude des Araneidae de Guyane française. V - Les genres Alpaida et Ocrepeira. Bulletin Mensuel de la Société Linnéenne de Lyon 83:14-30.

Framenau, V. W; ScharfF, N. \& Levi, H. W. 2009. Not from "Down Under": new synonymies and combinations for orb-weaving spiders (Araneae: Araneidae) erroneously reported from Australia. Zootaxa 2073:22-30.

Levi, H. W. 1988. The Neotropical orb-weaving spiders of the genus Alpaida (Araneae: Araneidae). Bulletin of the Museum of Comparative Zoology 151(7):365-487.

1992. Spiders of the orb-weaver genus Parawixia in America (Araneae: Araneidae). Bulletin of the Museum of Comparative Zoology 153:1-46.

Oliveira. R. R.; Lima, D. F.; Vianna, M. C.; Silva, M. \& Dela Monica, P. 1995. Levantamento Florístico do Parque Estadual da Pedra Branca. Relatório de acompanhamento. Rio de Janeiro, Fundação Estadual de Engenharia do Meio Ambiente. 29p.

Poeta, M. R. M. \& Lise, A. A. 2015. On the males of the orb-weaving spiders Alpaida nigrofrenata (Simon, 1895), A. machala Levi, 1988, and A. cisneros Levi, 1988 (Araneae, Araneidae) and a new synonymy. Zootaxa 4000(3):397-400.

Rodrigues, E. N. L. \& MendonçA JR, M. De S. 2011. Araneid orbweavers (Araneae, Araneidae) associated with riparian forests in southern Brazil: a new species, complementary descriptions and new records. Zootaxa 2759:60-68.

SAntos, K. P. \& Santos, A. J. 2010. Two new species of the orb-weaving spider genus Alpaida from Brazil (Araneae: Araneidae). Zootaxa 2336:61-66.

Saturnino, R.; Rodrigues, B. V. B. \& Bonaldo, A. B. 2015. Alpaida (Araneae: Araneidae) from the Amazon Basin and Ecuador: new species, new records and complementary descriptions. Zoologia 32(3):241-256.

World Sider Catalog. 2015. World Spider Catalog. version 15.5. Available at $<$ http://wsc.nmbe.ch>. Accessed on 20 May 2015. 